\title{
Coupling between ice microalgal productivity and the pelagic, metazoan food web in southeastern Hudson Bay: a synthesis of results*
}

\author{
JEFFREY A. RUNGE, JEAN-CLAUDE THERRIAULT, LOUIS LEGENDRE, R. GRANT INGRAM and \\ SERGE DEMERS
}

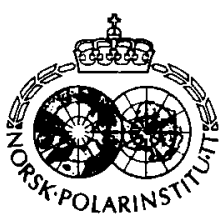

\begin{abstract}
Runge, J. A., Therriault, J-C., Legendre, L., Ingram, R. G. \& Demers, S. 1991: Coupling between ice microalgal productivity and the pelagic, metazoan food web in southeastern Hudson Bay: a synthesis of results. Pp. 325-338 in Sakshaug, E., Hopkins, C. C. E. \& Øritsland, N. A. (eds.): Proceedings of the Pro Mare Symposium on Polar Marine Ecology, Trondheim, 12-16 May 1990. Polar Research 10(2).

A multidisciplinary study of the ice algal production cycle in southeastern Hudson Bay in spring. 1986. provided an exceptional opportunity to observe trophic interaction between ice algae and metazoan zooplankton. During the ice algal bloom, females of the biomass-dominant copepod species, Calanus glacialis and Pseudocalanus spp. (predominantly $P$. minutus), grazed at night near the ice-waste interface. Fecding activity of these copepods significantly increased after the start of ice melt in mid-May when ice algae were released in large quantities into the water column. Copepod egg production was negligible during the ice algal bloom, then increased by approximately two orders of magnitude by mid-June. While changes in Calanus productivity can be attributed to increases in female-specific egg production rates alone. Pseudocalanus productivity was also substantially augmented by the appearance in late May of females of a second species. $P$. newmani. The data are consistent with the hypothesis that the major sources of nutrition for copepod production during this period are sedimenting ice algae (during and immediately after the bloom at the ice-water interface) and diatoms seeded from the interfacial layer and actively growing in the water column (in late May and Junne). Larvae of Arctic cod and sand lance, the yolk-sac stages of which were found in samples immediately after the onset of ice melt, were in a good position to feed on the resulting high concentrations of copepod nauplii in mid-June. These results therefore suggest a strong coupling between the ice algal production cycle and production cycles in the pelagic food web in this region.
\end{abstract}

J. A. Runge, J-C. Therriault and S. Demers, Ministère des Pêches et des Océans, Division d'océanographie biologique, Institut Maurice-Lamontagne, C.P. 1000, Mont Joli, Québec, Canada, G5H 3Z4; L. Legendre, Département de biologie, Université Laval, Québec, PQ, G1K 7P4; R. G. Ingram, Department of Meteorology, McGill University, 805 Sherbrooke St. West, Montreal, Quebec, Canada, H3A 2 K6.

\section{Introduction}

There is mounting evidence for a trophic interaction between zooplankton and the ice algal community in polar seas. Bradstreet \& Cross (1982), for example, found pennate diatoms endemic to sea ice among the gut contents of calanoid copepods and hyperiid amphipods captured under landfast ice off Baffin Island. The planktonic copepod, Pseudocalanus acuspes, swarms near the ice-water interface in spring in Barrow Strait and in laboratory experiments

*A contribution to the programs of GIROQ (Groupe interuniversitaire de recherches océanographiques du Québec) and the Maurice Lamontagne Institute (Biological Oceanography Division. Department of Fisheries and Occans, Canada) grazes without apparent difficulty on algae released from melted sea ice (Conover et al. 1986a, 1988). Euphausia superba in waters off the Antarctic Peninsula orients itself to the ice undersurface and rakes algal cells off the ice with its thoracic endopodites (Stretch et al. 1988). Larval and juvenile euphausids aggregate and feed in accumulations of ice algae on the undersurface of ice floes in the Weddell and Scotia Seas (Daly 1990). These observations indicate that grazing of zooplankton in seasonally ice-covered seas is not limited to the short spring/summer bloom of primary production in the water column.

It has been postulated that an extended grazing season influences secondary production in polar waters (Bradstreet \& Cross 1982). However, the 
relationship between under-ice grazing and zooplankton production and the importance of ice algal productivity to the functioning of pelagic food webs are only beginning to be understood. Some zooplankton species, such as E. superba, seem to be adept at locating and feeding on ice algae and associated microbial populations. This active interaction is conjectured to sustain euphausids in winter (Stretch et al. 1988), to the extent that availability of ice cover in nursery areas may influence recruitment success of Antarctic euphausiid populations (Daly 1990). In Arctic environments, it has been implicitly assumed that suspension-feeding zooplankton feed on dispersed, sedimenting organic material and diatom cells originating from the ice (Carey 1985). It could be argued in this case that the primary interaction occurs at the time of ice melt, when large numbers of ice algae are released and sink through the water column (Bradstreet \& Cross 1982). The influence of this potential, temporally-limited source of nutrition on zooplankton productivity is unknown. Recent observations (e.g. Conover et al. 1986a) suggest the ability of at least some Arctic zooplankton species to find high concentrations of ice algae near the ice-water interface prior to ice melt. Ice algal production may therefore have a more prolonged value to Arctic zooplankton, supplying copepods, for example, with a source of nutrition for development prior to the spring phytoplankton bloom (Bedo et al. 1990).

In the period 1985-86, a major interdisciplinary study of ice algal productivity and mechanisms of transfer to the pelagic food web was undertaken in Hudson Bay (Canada) by a group of scientists from McGill and Laval Universities and the Department of Fisheries and Oceans (Quebec region). High frequency sampling of physical and biological variables at a single station in conjunction with experiments conducted at nearby. land-based laboratory facilities provided an unprecedented view of events transpiring under first-year ice during spring in this region. We draw here from previously published work as well as from unpublished data in order to describe how zooplankton grazing and productivity were coupled to ice algal production before and after the start of ice melt. We suggest that this under-ice activity influences interactions at higher trophic levels in the pelagic food web, notably between zooplankton and larvae of fish common to the region.

\section{Methods}

The study site was located about $22 \mathrm{~km}$ north of the mouth of the Great Whale River, beyond the river's freshwater plume (Fig. 1). Water depth at the station was $40-60 \mathrm{~m}$, although depth of the surrounding water was over $100 \mathrm{~m}$. The Centre d'Études Nordiques, a field station maintained by Laval University in Kuujjuarapik, served as laboratory and base of operations. Sampling teams and equipment were transported to and from the ice by helicopter, single-engine airplane, or snowmobile.

Between 30 March and 19 May 1986, an ice camp was installed at the station. Routine physical and biological measurements were made, respectively, at two holes in the ice separated by a distance of approximately $300 \mathrm{~m}$. Water column salinity and temperature profiles were obtained with a Guildline 8770 CTD. Samples of algal biomass at the ice-water interface were taken by scuba divers using a 2-liter syringe sampler ("suction" or "slurp" gun) with an orifice diameter of $5 \mathrm{~cm}$. The sampler was positioned up against the bottom ice and pushed along the under-ice surface for a known distance, typically about $100 \mathrm{~cm}$. These samples were flown back to the shore laboratory, where subsamples were filtered onto Whatman GF/F filters and analysed spectrophotometrically for chlorophyll $a$ concentration (Barlow et al. 1988). Using the same analytic procedure, water column concentrations of chlorophyll $a$ were determined from Niskin bottle samples taken at $2.5,7.5,15$ and $30 \mathrm{~m}$ from the free water surface (to obtain distance from the bottom of the ice, the ice thickness must be subtracted). Subsamples from bottle casts at $2.5 \mathrm{~m}$ and $7.5 \mathrm{~m}$ were preserved in an acidic Lugol solution and algal species composition was later determined using an inverted microscope (Lund et al. 1958).

Observations of zooplankton abundance, vertical distribution, feeding, and productivity were made at sampling holes located between the sites of the other measurements. Zooplankton and ichthyoplankton were captured with a $333 \mu \mathrm{m}$ or $80 \mu \mathrm{m}$ mesh plankton net $(0.5 \mathrm{~m}$ or $1.25 \mathrm{~m}$ diameter) towed vertically from near bottom $(55 \mathrm{~m})$ to the surface. The catch was either frozen for analysis of grazing activity, which was estimated by the quantity of algal breakdown pigments in the guts of copepods as described in Runge \& Ingram $(1988,1991)$, or preserved in 
Fig. I. Location of the ice camp (Station 583, filled circle) in southeastern Hudson Bay.

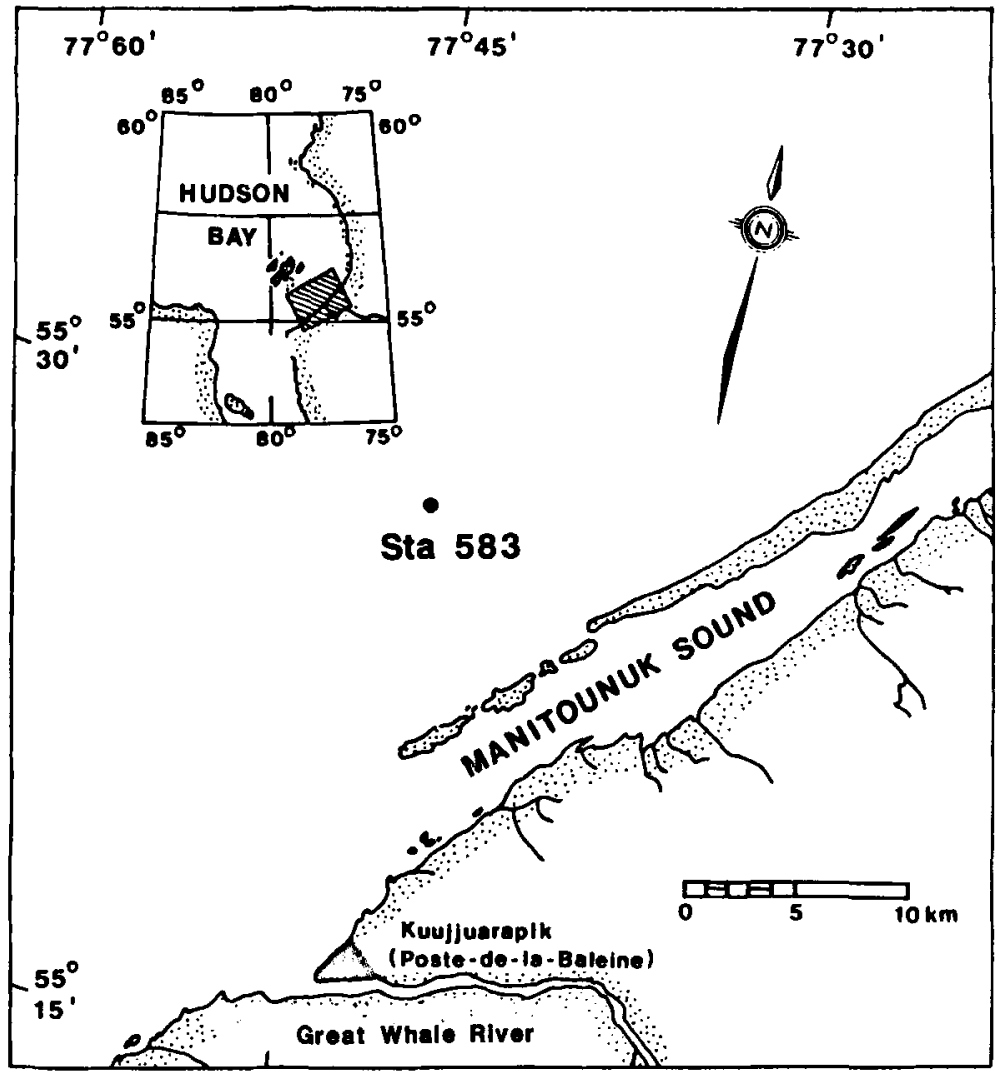

$4 \%$ formaldehyde for later identification and counting. Zooplankton near the ice-water interface was captured with a pump and the outflow $\left(5 \mathrm{l} \mathrm{s}^{-1}\right)$ was strained through a $80 \mu \mathrm{m}$ mesh net (Runge \& Ingram 1988, 1991). Fecal pellet flux was measured with 3 sets of sediment traps set in a $50 \mathrm{~m}$ triangle at depths of 10 to $15 \mathrm{~m}$ above the bottom (Tremblay et al. 1989).

In situ egg production rates of the planktonic copepod, Calanus glacialis, were estimated by counting the number of eggs released by females incubated at ambient temperature for a $24-48$ hour period immediately after capture. Procedural details as well as the method for measuring Calanus egg production rates in the laboratory are described in Tourangeau \& Runge (1991). Concentrations of eggs of species of Calanus (170-180 $\mu \mathrm{m}$ diameter), Pseudocalanus (105-140 $\mu \mathrm{m}$ diameter), and Oithona (55-65 $\mu \mathrm{m}$ diameter) were estimated from subsamples of the preserved, vertical net tow samples $(80 \mu \mathrm{m}$ mesh net). As Pseudocalanus and Oithona females carry their eggs until hatching, counts for these species included eggs in attached and detached egg sacs or egg masses as well as free eggs that had been separated during the sampling procedure. No adjustment was made for the possibility that Oithona eggs were systematically undersampled because of loss through the mesh of the net. Pseudocalanus egg production rates were calculated as the total number of Pseudocalanus eggs divided by the number of females and the egg development time.

After the ice camp was dismantled during the third week of May due to deteriorating ice conditions, a helicopter was used to continue sampling at or very near the original station. The helicopter was fitted with a portable winch and rigged for CTD and bottle casts and for vertical tows with a $0.5-\mathrm{m}$ diameter, $80-\mu \mathrm{m}$ mesh net.

\section{Results and discussion}

\section{Physical events}

In the spring of 1986, air temperatures were consistently above $0^{\circ} \mathrm{C}$ after the first week of May 


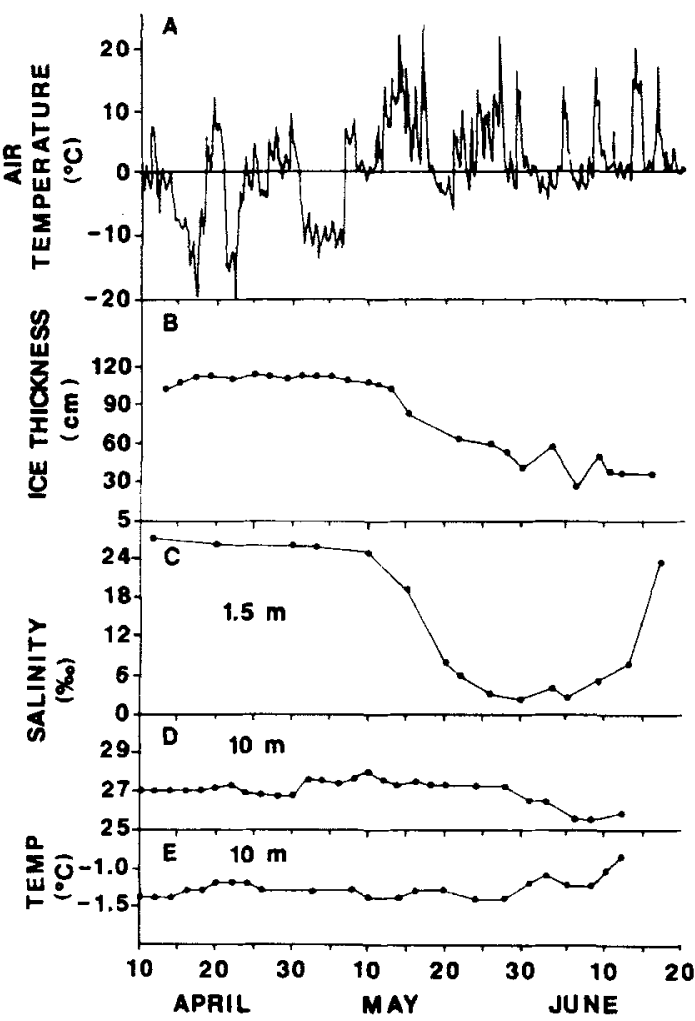

Fig. 2. Physical characteristics in spring 1986. A. Air temperature, recorded hourly at the Atmospheric Environment Service station in Kuujjuarapik; B. Ice thickness; C. Salinity at $1.5 \mathrm{~m}$; $D$. Salinity at $10 \mathrm{~m} ; \mathbf{E}$. Temperature at $10 \mathrm{~m}$. Depths are relative to the free surface in ice hole or open water (i.e. subtract ice thickness to get distance from under-ice surface).

(Fig. 2A). Prior to this time, ice thickness remained at $100-110 \mathrm{~cm}$ (Fig. 2B) despite intervals of above-freezing temperatures. The onset of ice melt occurred between 10 and 20 May, during which time air temperatures frequently exceeded $10^{\circ} \mathrm{C}$. Ice thickness was reduced by $40 \%$ (Fig. 2B) resulting in the formation of a freshwater lens (Fig. 2C), the depth of which was less than $4 \mathrm{~m}$ (Lepage \& Ingram 1991). Salinity and temperature at $5 \mathrm{~m}$ deeper (Fig. 2D and E) were relatively unaffected by events at the surface until early June. Changes at this time were related to wind-induced vertical mixing in open water as the ice cover broke apart (Lepage \& Ingram 1991).

\section{Algal biomass and composition}

An important feature of the ice-algal productivity in this region is the presence (offshore of the freshwater plume of the Great Whale River) of an ice-algal assemblage situated at the interface between the bottom of the ice and the water column (Gosselin et al. 1985; Barlow et al. 1988; Runge \& Ingram 1988, 1991). This interfacial layer, $1-2 \mathrm{~cm}$ thick, consists of free floating or very loosely attached ice crystals to which algae seem to adhere. It is this layer that was sampled by divers with the suction gun.

The bloom of the interfacial algal community started in early April. Divers observed that the intensity of brown color at the interface, an indication of biomass, was patchy. Chlorophyll concentrations in the denser patches of algae were $100-1000 \mu$ liter $^{-1}$ (Fig. 3A). Estimates of areal biomass (Fig. 3B), which take into account the distribution of patches of different density, indicate sedimentation of ice-algal aggregates following a short atmospheric warming event in the third week in April (Tremblay et al. 1989). The bloom nevertheless persisted until 13 May (Fig. $3 \mathrm{~A}$ and $\mathrm{B}$ ), when events associated with the start of ice melt (Fig. 2) resulted in release of algae from the interface into the water column (Tremblay et al. 1989).

Concentrations in the water column (approximately 1.5 and $6.5 \mathrm{~m}$ below the bottom of the ice,

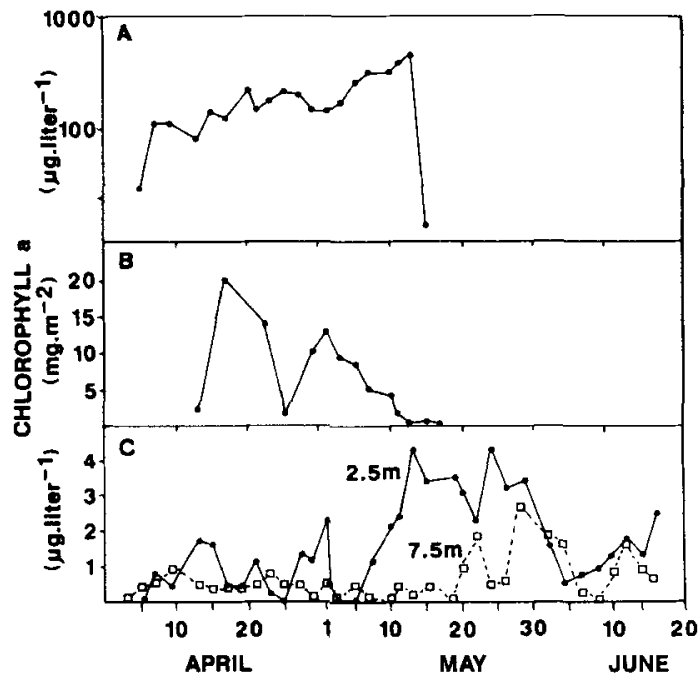

Fig. 3. Chlorophyll a concentrations ( $\mu \mathrm{g} \cdot \mathrm{1}^{-1}$ ) during spring 1986: A. In the interfacial layer (sampled by divers in high density patches of ice algae: Michel et al. 1988); B. In the interfacial layer (mean areal biomass), based on estimated contribution of patches of high. medium, and low algal density (from Tremblay et al. 1989); C. In the water column at $2.5 \mathrm{~m}$ and $7.5 \mathrm{~m}$. 


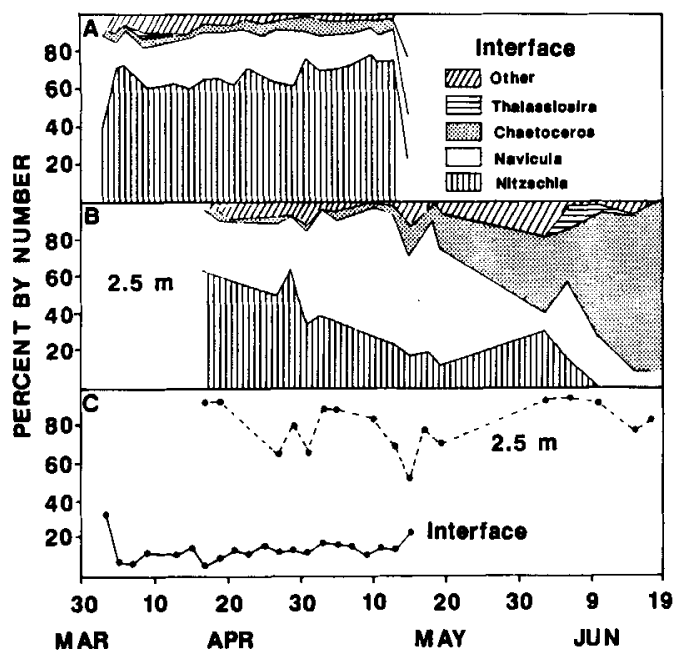

Fig. 4. Algal species composition (percentage of total cell counts less microflagellates) in 1986. A. In the interfacial layer; $B$. At $2.5 \mathrm{~m}$ (same key as panel A); C. Contribution (percentage of total cell counts) of microflagellates (solid line, interface; broken line, $2.5 \mathrm{~m}$ ).

Fig. 3C) during the ice algal bloom were several orders of magnitude lower than concentrations at the interface (see also Tremblay et al. 1989). During the time of ice melt, water column concentrations increased substantially, to $2-4 \mu \mathrm{g}$ chlorophyll $a$ liter $^{-1}$ by the end of May (Fig. 3C) (Tremblay et al. 1989). Concentrations at $2.5 \mathrm{~m}$ were lower in June $(0.5-2.5 \mu \mathrm{g}$ chlorophyll $a$ liter $^{-1}$ ). However, because the freshwater lens deepened in early June, samples taken from $2.5 \mathrm{~m}$ during the first two weeks in June represent low salinity water and may not be indicative of maximum chlorophyll concentrations occurring somewhat deeper, at or below the pycnocline.

The ice-algal community at the interface was dominated by the pennate diatom Nitzschia frigida, which made up between $40-70 \%$ (by number) of algae other than microflagellates (Fig. 4A). The two other predominant species were Navicula pelagica and Chaetoceros septentrionalis. Microflagellates constituted $10-20 \%$ of the total number of cells in the samples from the interface (Fig. 4C). Their contribution may have been underestimated because of incomplete sedimentation in settling chambers ( $R$. Gradinger pers. comm.).

The species composition of algae in the water column at $2.5 \mathrm{~m}$ closely resembled that in the interfacial layer until the end of April (Fig. 4B). By this time, Navicula pelagica had become relatively more abundant in the water column. This species predominated in early May and then was succeeded by Chaetoceros septentrionalis. At the end of sampling period in mid-June, $C$. septentrionalis constituted more than $80 \%$ of algae other than microflagellates in the surface waters. The same temporal pattern occurred in the algal composition at $7.5 \mathrm{~m}$.

As shown in Fig. 4C, microflagellates were proportionately much more abundant in the water column, making up between 60 and $80 \%$ of the total number of cells. However, because diatom concentrations in the water column during the ice-algal bloom were relatively much lower than at the interface, the flagellate concentration in absolute terms was actually higher in the interfacial layer during April and early May.

\section{Zooplankton grazing and vertical migration in relation to the ice algal bloom}

Our examination of the coupling between zooplankton and ice macroalgae focused on females of two genera of suspension-feeding copepods, Calanus and Pseudocalanus. Comparisons (performed once in 1985 and again in 1986) of zooplankton composition in the entire water column with the planktonic species assemblages present just below the ice-water interface indicated that these copepods had the greatest potential for interaction with the interfacial algal community (Fig. 5). Among the larger zooplankton, chaetognaths and medusae were, respectively, the most abundant taxa in the water column, whereas chaetognaths and Calanus glacialis, $90 \%$ of which were females, clearly predominated at night near the interface (Fig. 5). Among the smaller zooplankton, species of Pseudocalanus and the cyclopoid copepods, Oithona similis and Oncaea borealis, were most abundant in the water column. Pseudocalanus, however, singly predominated close to the interface. The Pseudocalanus population consisted primarily of older copepodite stages but also included adult females. In late April, $P$. minutus constituted approximately $95 \%$ of the Pseudocalanus female population; $P$. newmani and a small number of $P$. acuspes were also present (see Frost 1989 for a recent taxonomic revision of the genus). As will be discussed below, the makeup of the Pseudocalanus female population shifted after ice melt. 


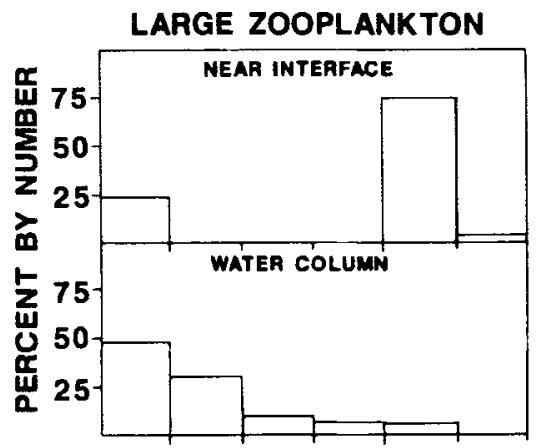

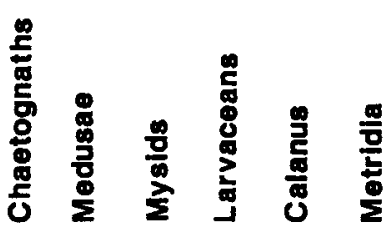

SMALL ZOOPLANKTON
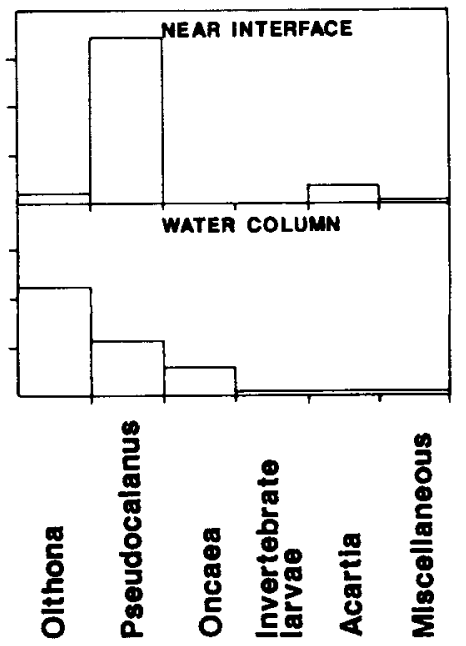

Fig. 5. Zooplankton composition in a sample collected at 0030 (local time). 26 April 1986, using a pump with an inlet located at approximately $20 \mathrm{~cm}$ below the interfacial layer (upper panels) and in a vertical tow from the bottom to the surface taken within twelve hours of the pump sample (lower panels). Miscellaneous category includes species of the copepod, Microalanus pygmaeus. The mesh size of the tow net and the net used to concentrate the pump outflow was $80 \mu \mathrm{m}$.
Over the two years of our study, there was a consistent diel migration by Calanus and $P_{\text {seudo- }}$ calanus females to a region very near the underice surface during the ice-algal bloom (e.g. Fig. 6). Calanus appeared at the surface 1-2 hours after sunset and invariably departed at first light before sunrise. Pseudocalanus females typically arrived somewhat earlier. The minimum between midnight and 0200 in the nighttime surface abun- dance of Calanus was a recurrent observation (Runge \& Ingram 1988, 1991), suggesting the phenomenon of 'midnight sinking' found in other Calanus migration studies (e.g. Simard et al. 1985). A profile of the upper $5.5 \mathrm{~m}$ of the water column at night shows that both species were 34 times more abundant in the sample taken closest to the interface (Fig. 7). This suggests that $\mathrm{Cal}$ anus and Pseudocalanus females were not merely

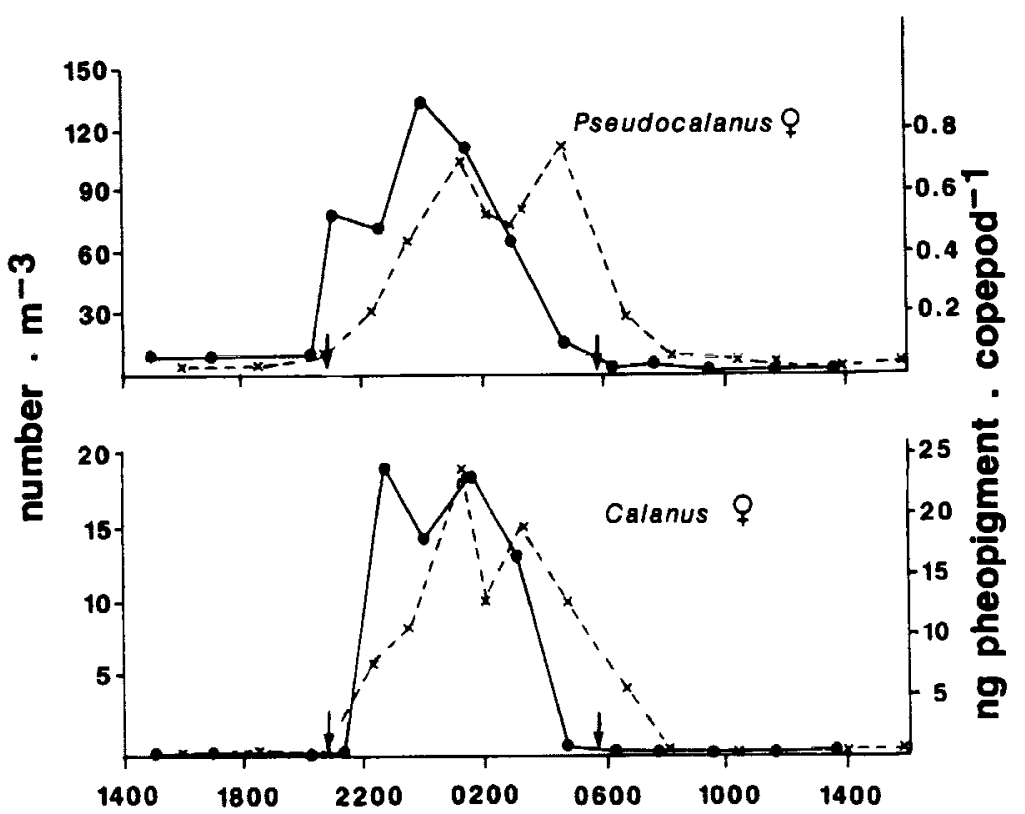

Fig. 6. Abundance of Pseudocalanus and Culanus females in pump samples taken at $0.2 \mathrm{~m}$ every $1-3$ hours during a 24-hour period in late April (solid line) and quantity of pheopigments in fernale Pseudocalanus and Calanus captured in vertical net tows (bottomsurface) over the same 24 hour period (broken line). Arrows denote time of sunset and sunrise. Adapted from Runge \& Ingram (1991). 
Fig. 7. Nighttime, surface vertical distribution of Pseudocalanus and Calanus females on April 26 (solid line) and on 15 May (broken line). Pump samples taken between 2130 and 2330 . Adapted from Runge \& Ingram (1991).
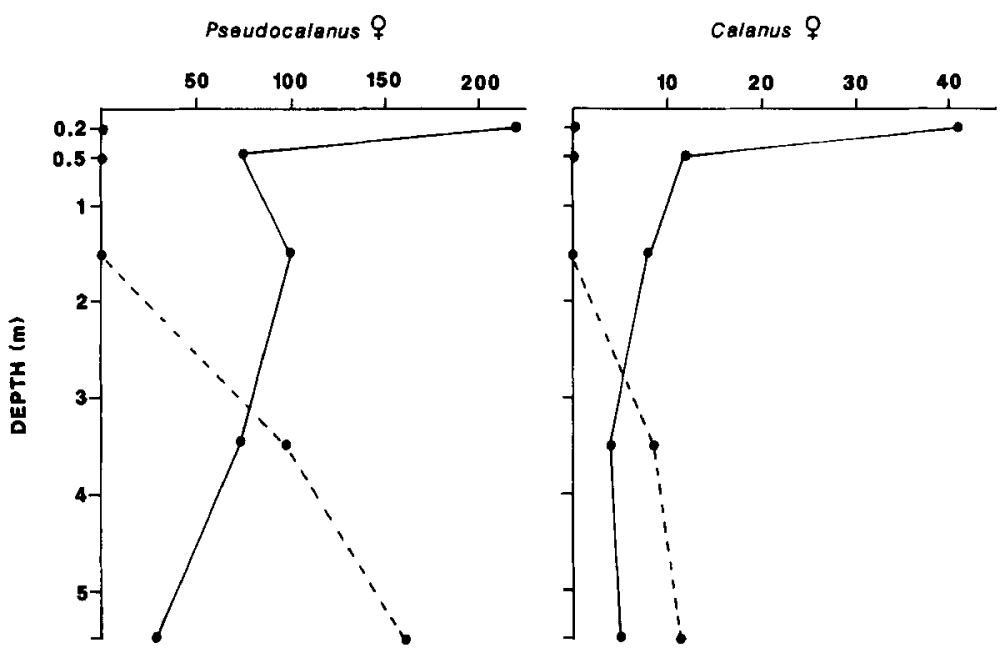

making a general migration to surface waters at night, but rather were moving directly towards the ice-water interfacial layer.

Observations of daily feeding patterns of Calanus and Pseudocalanus corresponded well with the migration to near the interface (Fig. 6; see also Runge \& Ingram 1988, 1991). Breakdown

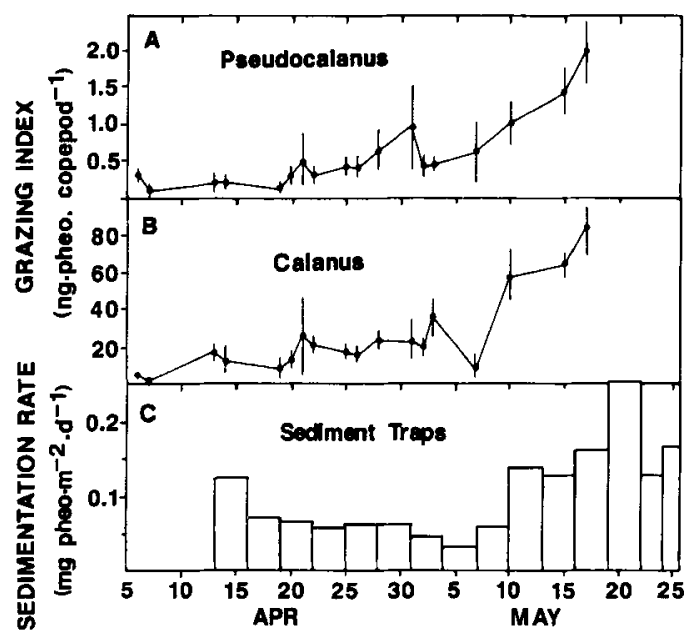

Fig. 8. Index of grazing by Pseudocalanus and Calanus females (upper panels) and sedimentation rate of pheopigments in sediment traps moored $10-15 \mathrm{~m}$ above the bottom at sites within $0.3 \mathrm{~km}$ of the zooplankton sampling location. Grazing index represents the quantity of pheopigments in guts of copepods sampled with a vertical net tow approximately 3 hours after sunset. Sedimented material was collected every 2-3 days. Adapted from Tremblay et al. (1989) and Runge \& Ingram (1991). products of algal pigments in the copepod guts started to increase after sunset and reached a maximum level 3-4 hours later. Gut pigments declined in early morning, lagging the descent from the surface by 1-3 hours.

Grazing by Calanus and Pseudocalanus appeared to intensify after the start of ice melt, as the level of pheopigments in copepod guts, measured at the same relative time in their daily feeding cycle, increased threefold to fourfold between 7 May and 15 May (Fig. 8A and B). It is conceivable that these higher gut pigment levels resulted from rapid changes in chlorophyll content of individual cells or to a decrease in pheopigment loss rates (e.g. Conover et al. 1986b). However, measurements of the pheopigment flux (which was correlated with the total fecal pellet flux: Tremblay et al. 1989) in nearby sediment traps increased by the same order of magnitude (Fig. $8 \mathrm{C}$ ) during this period, confirming that the pheopigment increase did indeed reflect higher ingestion rates. This change in feeding activity is also reflected in the nighttime, vertical distribution of females (Fig. 7). While continuing to feed with a diel rhythm (Runge \& Ingram 1991), females were by mid-May no longer concentrating near the interface at night.

\section{Under-ice zooplankton productivity}

Fig. 9 summarises observations of the productivity of Calanus and Pseudocalanus females during the study period; the top two panels show algal concentrations and the grazing index from previous 


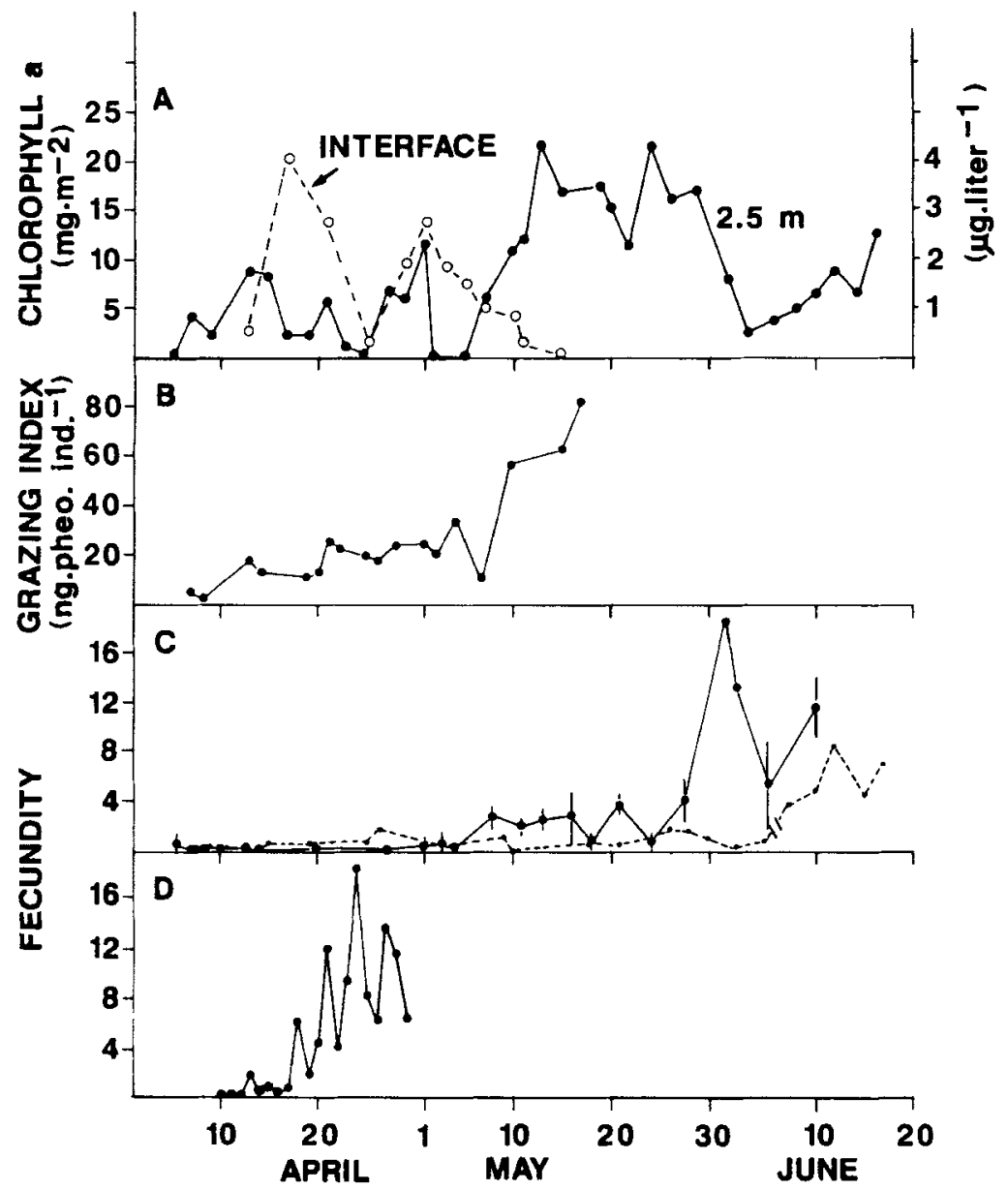

Fig. 9. Productivity of Calanus glacialis and Pseudocalanus sp. females in spring 1986. A. For reference, biomass $(\mathrm{mg}$ chlorophyll a $\cdot \mathrm{m}^{-2}$ ) of algae in the interface and concentration (mg chlorophyll a $\left.\mathrm{m}^{-3}\right)$ at 2.5 m (from Fig. 3); B. Grazing index for Calanus glacialis (from Fig. 8); C. Estimates of in situ egg production rate (eggs female $\left.{ }^{-1} \cdot \mathrm{d}^{-1}\right)$ of Calanus glacialis (solid line) and egg ratio (eggs $\cdot$ female $^{-1}$ ) of Pseudocalanus spp. (broken line, break in line indicating approximate time of species change):

D. Egg production rates of C. glacialis females captured on 10 April and maintained in the laboratory under conditions of supcrabundant food and ambient temperature. Adapted from Tourangcau \& Runge (1991) and unpublished data.

figures for reference. Because Calanus glacialis releases its eggs directly into the water, an incubation technique was used to estimate daily egg production per female capita. Calanus egg production rates were negligible during the time of feeding near the interface but then increased to high, near maximal, values in late May and early June (Fig. 9C). Females captured from the ice station and fed superabundant food in the laboratory at near-ambient temperatures attained similar maximum rates several weeks ahead of their counterparts in the wild (Fig. 9D). This indicates that the Calanus females were food-limited during the ice algal bloom and had sufficient food for egg production only after ice melt began.

Production of Pseudocalanus females was estimated from the eggs to female ratio (Edmondson 1965; Ohman 1985). Fecundity was low in April and May, then increased in the second week in June, somewhat later than Calanus (Fig. 9C). The shift in species composition of females from $P$. minutus to $P$. newmani occurred between 24 May and 8 June (Fig. 10), so the increase in fecundity is correlated with the advent of the smaller species. The egg ratio reflects the daily egg production rate of Pseudocalanus since the water column temperature, which controls egg development time and consequently the time interval between clutches, was relatively constant over the course of the season (Fig. 2E). Extrapolation of equations from McLaren et al. (1989) yields egg development times on the order of 12-13 days for both species at $-1{ }^{\circ} \mathrm{C}$. P. minutus egg production rates in May were, therefore, less than 0.15 eggs $\cdot$ female ${ }^{-1} \cdot \mathrm{d}^{-1}$. In mid-June, Pseudocalanus ( $P$. minutus and $P$. newmani combined, as eggs were not identified according to species) was producing eggs at the rate of $0.3-0.6$ eggs $\cdot$ female ${ }^{-1} \cdot \mathrm{d}^{-1}$.

In general, water column concentrations of eggs 
Fig. 10. Abundance of Pseudocalanus females estimated from single, water column tows (one per sampling date) with a $0.5 \mathrm{~m}$ diameter, $80-\mu \mathrm{m}$ mesh net. Solid line: $P$. minutus (modal prosome length: $1.1-1.2 \mathrm{~mm}$ ).

Broken line: $P$. newmani (modal prosome length: $0.7-0.8 \mathrm{~mm}$ ).
Fig. II. Water column concentrations of eggs of 3 predominant copepod taxa (note Pseudocalanus and Oithona eggs are attached to females) estimated from single, water column tows. Unconnected symbols at bottom show dates where no eggs of that genus were found.
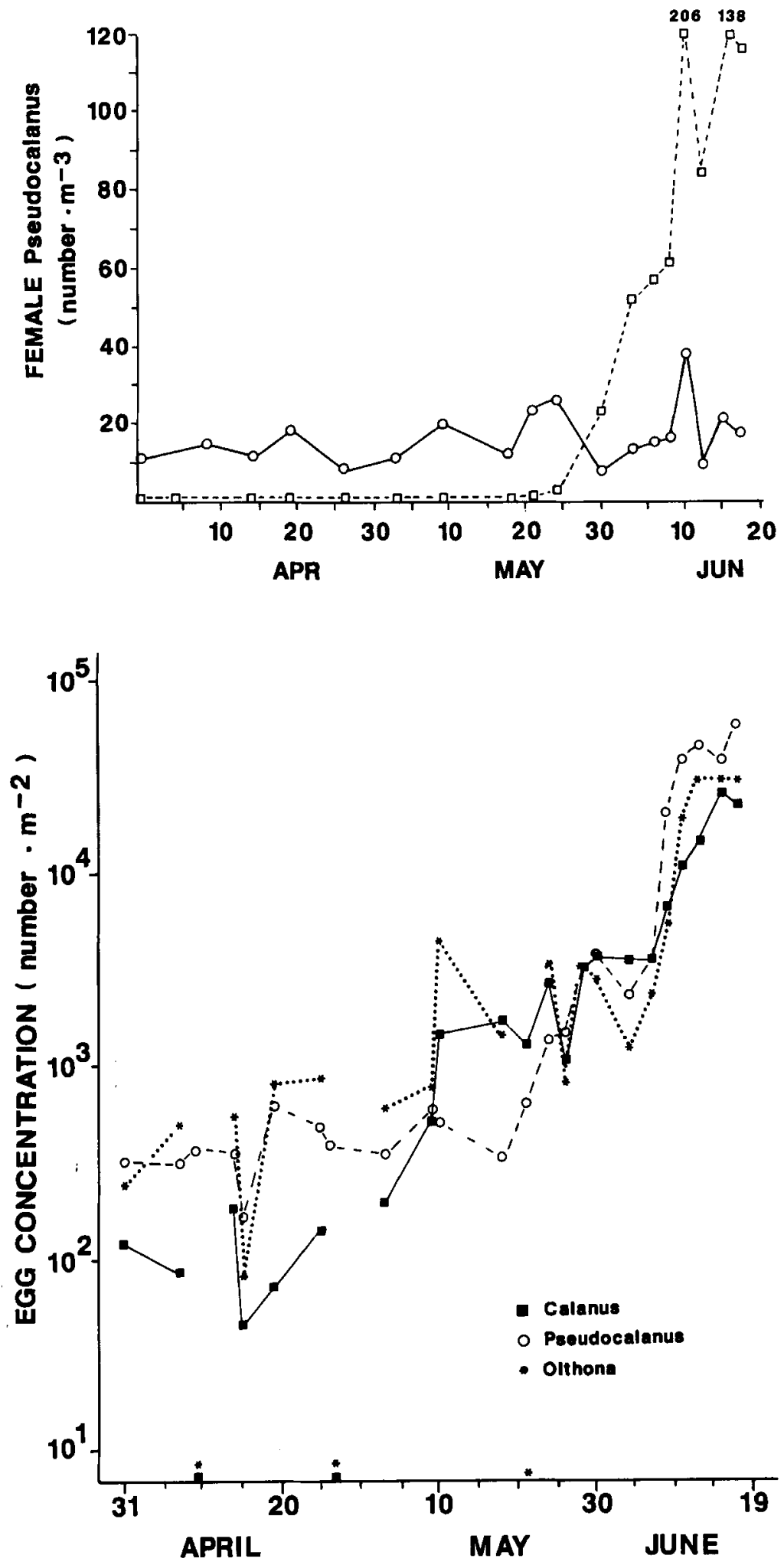
(Fig. 11) conform with the observations of per capita productivity. The density of Calanus eggs rose by approximately an order of magnitude in Mid-May and by another factor of 10 in early June. These changes reflect increased egg production rates per female, as the Calanus female density during the study period remained relatively constant (Tourangeau \& Runge 1991). The number of Pseudocalanus eggs in the water column rose by two orders of magnitude as well, starting in late May. The increase in Pseudocalanus production is due to a substantial augmentation in the number of female $P$. newmani by late May (Fig. 10) as well as to the elevation in egg production rates in June. While we do not discuss here the functioning of the Oithona population, we note that the number of eggs of this species also rose substantially at the same time in early June (Fig. 10). In 1986. therefore, timing of the major spring productivity event of the three most abundant pelagic copepods at this station lagged the start of ice melt by $3-4$ weeks.

\section{Ichthyoplankion}

Arctic cod (Boreogadus saida) and sandlance (Ammodytes sp.) dominated the ichthyoplankton captured in the plankton tows at the station. Sculpin (Myoxocephalus scorpius) and capelin (Mallotus villosus) were also present. Young Boreogadus (5.5-7.5 mm total length) and Ammodytes (6.5-8.5 $\mathrm{mm}$ total length) larvae started to appear in mid-May and were subsequently observed in densities up to $6.56 \cdot \mathrm{m}^{-2}$ and $15 \cdot \mathrm{m}^{-2}$, respectively (Fig. 12). Yolk sacs were present in most larvae in May. Mean densities in replicate vertical tows from the bottom to the surface and from $15 \mathrm{~m}$ to the surface were nearly identical during the day and at night, indicating that larvae of both species were residing in the upper $15 \mathrm{~m}$ of the water column.

The trophic role of ice algae in the pelagic food web: zooplankton grazing

Our observations suggest a trophic interaction between ice-algal production and species of zooplankton in southeastern Hudson Bay. In April, when ice algae are concentrated at the interface. Calanus and Pseudocalanus migrated near the interface to graze. Our pumping system was not designed to precisely sample the interfacial layer, so we do not know whether the cope-

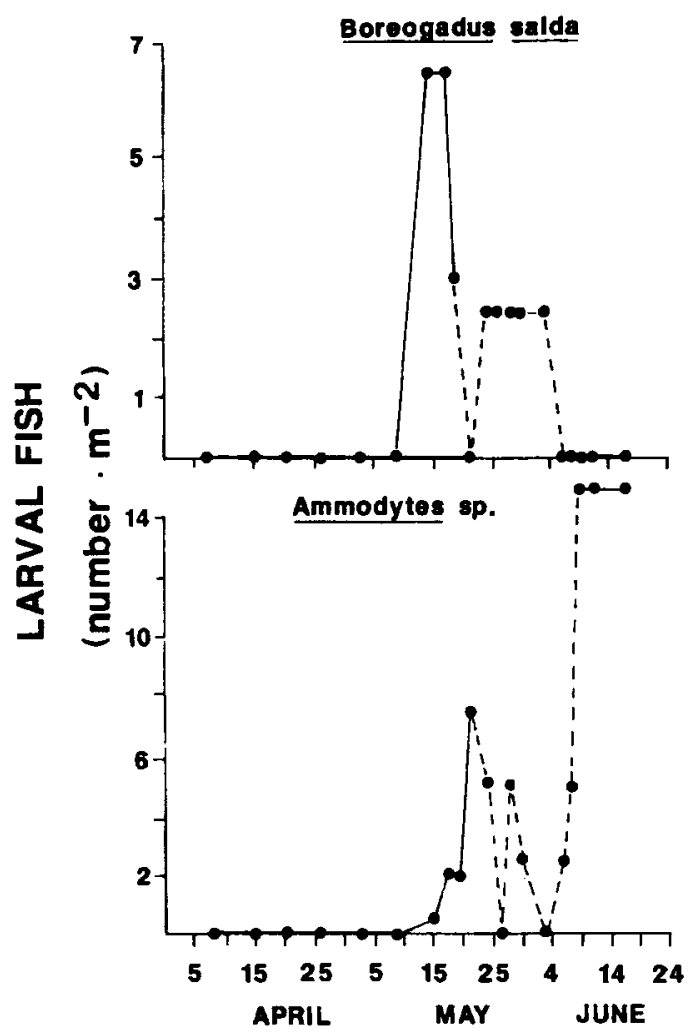

Fig. 12. Density (number $\cdot \mathrm{m}^{-2}$ ) of fish larvae under ice and during ice melt in southeastern Hudson Bay. April-June 1986. Larvac captured with a $333-\mu \mathrm{m}$ mesh, $0.5 \mathrm{~m}$ diameter net (broken line) towed vertically from near bottom to the surface.

pods actually fed within the first few centimetres of the interface (Runge \& Ingram 1991). The low, food-limited egg production rates and the relationship between gut pigment levels and water column concentrations at $2.5 \mathrm{~m}$ (Fig. 9) suggest that most females were grazing on suspended algae just below the interfacial layer. In either case, our results point convincingly to production of ice algae at the interface as a major source of food during this period. The data include observations of ice diatom fragments in Calanus gut contents (Runge \& Ingram 1988, 1991) and the finding of a nearly identical diatom species composition in the water column and at the interface in April (Fig. 4), which indicates that water column diatoms are sedimenting from rather than growing independently of the interface at this time. Moreover, in 1985, when we were able to observe copepod grazing before the interfacial bloom, we found that pheopigments in Calanus 
and Pseudocalanus digestive tracts increased tenfold after the bloom had commenced (Runge \& Ingram 1988). This provides evidence for strong linkage between the start of the grazing season for Calanus and Pseudocalanus and the timing of the interfacial bloom.

Ice microalgae continued to play a major role in the nutrition of zooplankton after the decline of the interfacial bloom in mid-May. Sediment trap measurements of vertical fluxes of chlorophyll $a$ and pheopigments indicate that a large proportion of the ice algal biomass remained suspended in the water column after release from the interface (Tremblay et al. 1989). Calanus and Pseudocalanus responded by feeding deeper in the water column and at higher rates (reflected by increases in both gut pigment content and fecal pellet flux) than previously observed. While Nitzschia species, which dominated both the interfacial and water column diatom assemblages in April, disappeared from the water column by early June, Navicula pelagica and Chaetoceros septentrionalis persisted, the latter species becoming overwhelmingly dominant by mid-June. Since both these species were prominent in the interfacial assemblage, we cannot reject the hypothesis that the algal production in the water column in the weeks after initiation of ice melt was seeded by release of algae from the interface. Although we were not able to measure feeding after ice melt, it is clear from the productivity measurements that grazing rates continued to be high during this latter period. Hence the trophic ramifications of the ice algal bloom to zooplankton may extend well after its disappearance from the interface.

\section{Coupling between ice algal and zooplankton production cycles}

Our study focused on the relationship between under-ice grazing and reproduction of the dominant copepods. The timing and the magnitude of egg production are key determinants of both the dynamics of copepod populations in early spring and the availability of prey for larval fish. Observations of copepod egg production therefore provide clues as to how the ice algal production cycle may influence the production cycles of species in the pelagic food web.

Interpretation of early spring patterns of egg production must take into account copepod gonad maturation cycles. Calanus and Pseudocalanus require an internal supply of developed oocytes and stored male gametes before egg production is possible. We assume that supply of the latter is not limited and eggs are always fertilised. The extent to which oocyte development depends on an external food source is not known with certainty. Studies of reproductive behaviour of $C$. finmarchicus (Tande \& Hopkins 1981) and $C$. pacificus (Runge 1984) indicate that vitellogenesis in these species requires contemporaneously ingested material. However, Smith (1990) observed that female Calanus glacialis in Fram Strait released eggs in early spring in the apparent absence of an external food supply, implying that internal body stores may be used to bring oocytes completely to maturity.

Our findings reveal some of the complexity in the relationship between copepod grazing and production cycles. In mid-April, most of the female Calanus population carried undeveloped oocytes. Only a very small proportion $(<5 \%)$ were ready to release eggs (Tourangeau \& Runge 1991, Fig. 2), accounting for the very low concentration of eggs in the water column at this time (Fig. 11). Laboratory experiments conducted at $0^{\circ} \mathrm{C}$ indicate that, on 10 April, Calanus females could have brought gonads to maturity and produced eggs at near maximal rates by 21 April in the presence of unlimiting food (Fig. 9D). On this date in the wild population, on the other hand, only $10 \%$ of the females were reproductively mature (Tourangeau \& Runge 1991), and egg production rates and water column egg densities were still very low (Figs. 9C and 11).

What, then, is the impact of grazing during the interfacial bloom and after ice melt on Calanus production? In contrast to Smith's (1990) results, most of the population in southeastern Hudson Bay apparently required an external source of food to bring oocytes through the final stages of development. Tourangeau \& Runge (1991) hypothesised that, while Calanus glacialis in southeastern Hudson Bay was clearly food-limited in April, grazing during this period nevertheless accelerated maturation of oocytes; females were therefore better prepared to convert food available after release of ice algae from the interface into egg production. Higher ingestion rates after the start of ice melt mitigated foodlimitation, as C. glacialis attained near-maximal egg production rates sometime in the third or fourth week in May. These rates continued in June during the Chaetoceros-dominated growth 
in the water column. For Calanus, we conclude that under-ice grazing, associated with ice-algal production at the interface, release of algae into the water column, and subsequent phytoplankton growth influence both the timing and magnitude of the number of eggs produced.

Interpretation of Pseudocalanus production in relation to under-ice grazing must also take into account the shift in species composition in late May. According to Corkett \& McLaren (1978, Fig. 21), food-satiated females in the size range of $P$. minutus (1.1-1.2 $\mathrm{mm}$ ) would produce $1.5-$ 2.5 eggs $\cdot$ female $^{-1} \cdot \mathrm{d}^{-1}$ at $-1^{\circ} \mathrm{C}$. It is not known what proportion of female $P$. minutus in May were still preproductive, which would reduce theoretical maximum rates for the wild population (Ohman 1985). Nevertheless, the observed egg production rates were an order of magnitude lower than the potential maximum, indicating that this species was food-limited in April and May. $P$. newmani females rapidly increased in abundance at the end of May and were producing eggs in June. Whether or not $P$. newmani achieved maximum rates $(0.5-0.8 \mathrm{eggs}$. female ${ }^{-1} \cdot \mathrm{d}^{-1}$ for females of equivalent body size) cannot be ascertained until the relative contribution of the two species to the total Pseudocalanus egg production is determined.

We hypothesise that Pseudocalanus was utilising ice-algal and subsequent water column production for both egg production and for growth and development of copepodite stages, the latter manifesting itself as the large increase in female density of $P$. newmani in late May (cf. Bedo et al. 1990). At this point in our analysis, however, there remain unanswered questions, such as why fecundity of $P$. minutus did not increase earlier in the season and what contribution this species makes to the burst of egg production in June. We cannot, as well, rule out the possibilities that nutrition from concurrent microbial production or advection of females to the study site were also important factors influencing the dynamics of Pseudocalanus during the study period.

This under-ice egg production may contribute significantly to the population growth rates of Calanus and Pseudocalanus in the region. Cold temperatures of Hudson Bay waters in late spring and early summer impede the development of offspring. At $-1^{\circ} \mathrm{C}$. for example, eggs develop to copepodite stage $\mathrm{CI}$ in 40-60 days (Corkett \& McLaren 1986; McLaren et al. 1989). Tourangeau \& Runge (1991) suggested that accelerated oogenesis and subsequent egg production improves the timing between the appearance of naupliar and copepodite feeding stages and the cycle of primary production in the water column. We do not know whether diatom production continues or is succeeded by regenerative microbial production after ice disappearance in late June, nor do we understand well the suitability of the latter for growth and development of early life history stages of copepods. The question that arises is whether early-hatched offspring grow and survive at higher rates, because of their timing with the start of water column production, than offspring spawned in mid-June and later. If this is the case, eggs produced at the time of ice melt would make a disproportionately high contribution to recruitment into these copepod populations.

\section{Zooplankton production and fish recruitment cycles}

The abundance of Boreogadus larvae $\left(2-7 \cdot \mathrm{m}^{-2}\right.$ or $13-47 \cdot 100 \mathrm{~m}^{-3}$ ) found in $0-15 \mathrm{~m}$ plankton tows in May is comparable to reported abundance in other regions of the Canadian Arctic and subarctic (Sekerak 1982; Bradstreet et al. 1986). In general, Boreogadus densities range from 0.02 to $243 \cdot 100 \mathrm{~m}^{-3}$ (median: $4 \cdot 100 \mathrm{~m}^{-3}$ ), although many of these estimates are based on samples of the water column rather than the surface layer where Boreogadus are known to reside (Sekerak 1982). Using a $0.5 \mathrm{~m}$ plankton net towed at $10 \mathrm{~m}$, Sekerak (1982) found mean densities of 20 larvae $\cdot 100 \mathrm{~m}^{-3}$ in Lancaster Sound and Baffin Bay.

Studies of Boreogadus larvae (summarised in Sekerak 1982 and Bradstreet et al. 1986) were carried out in the summer and refer, with few exceptions, to populations in the high Arctic, $10-20^{\circ}$ latitude further north. These larvae were somewhat larger than observed in this study; modal lengths of larvae in the Lancaster Sound study, for example, were 11-13 mm (Sekerak 1982). In this and other studies, the time of appearance of newly hatched larvae occurred before the sampling period and therefore was not recorded. However, by back-extrapolation using Sekerak's (1982) regressions of larval length on date, we calculate that the larvae present in Lancaster Sound in late July would have been $6.5 \mathrm{~mm}$ in early June, approximately 6 weeks later than the Hudson Bay larvae. 
This analysis suggests that the correlation between the appearance of Boreogadus and Ammodytes larvae and the time of ice melt was not just a coincidence, but rather reveals an interaction between the under-ice zooplankton production and fish recruitment processes. Studies of the dietary composition of larval Boreogadus show that the majority of food items are typically eggs and nauplii of calanoid copepods (Bradstreet et al. 1986). We conjecture that the larval fish in Hudson Bay would have used up yolk reserves by June and therefore were timed to commence feeding on eggs and (consequently) nauplii present in increasing numbers in the water column.

Our conclusions about the channelling of ice algal production into the pelagic food web have important implications for understanding variability in the cycles of zooplankton production and fish recruitment in southeastern Hudson Bay. The characteristics of the ice algal bloom in the region are variable from year to year, due in part to interannual variability in climatic factors. In 1985 , for example, the interfacial ice algal bloom started later, in the third week in April, but rapidly attained concentrations $>600 \mu \mathrm{g}$ chl a liter $^{-1}$. Release from the interface occurred between 913 May (Runge \& Ingram 1988). We hypothesise that variability in the timing and magnitude of the ice algal bloom influences the productivity cycles of Calanus and Pseudocalanus in southeastern Hudson Bay and consequently the timing of food availability to larvae of Arctic cod and sand lance. Our results therefore raise the possibility of a strong linkage (sensu Runge 1988) in the spring productivity cycles of the region's pelagic food web.

As a final note, it is recognised that our interpretation is based on results from a single year at a single station; logistical considerations prohibited broader spatial coverage that would have provided a more comprehensive view of heterogeneity and the role of advection. While our conclusions must be considered as hypotheses subject to future verification, the results of the study show at the very least that the potential for strong trophic interaction between ice algal production and members of the Arctic pelagic food web cannot be ignored.

Acknowledgements. - This research was funded by a strategic grant from the Natural Sciences and Engineering Research Counci of Canada (NSERC), a Donner Foundation grant, the Department of Fisheries and Oceans, Canada. NSERC oper- ating grants to individual investigators and the Quebec Fonds pour la formation de chercheurs et l'aide à la recherche (FCAR). M. Gosselin, S. Lepage, A. Mohammed, C. Michel, K. Shirasawa, S. Tourangeau and C. Tremblay contributed to the results presented in this paper. C. Abou-Debs identified Pseudocalanus species with the assistance of J.-M. Sevigny. L. Van Guelpen confirmed identification of fish larvac. P. Jalbert's excellent technique was of great benefit to the zooplankton program. The assistance of E. Bonneau, J.-C. Deguise, M. Dubé, A. Gagné, P. Joly, P. Larouche, P. Peltola, N. Têtu and others who made this project work is gratefully acknowledged. Figures were prepared by L. Corriveau. We thank $R$. J. Conover and an anonymous referee for comments on an earlier version of the manuscript. This paper was presented as part of the Symposium on Polar Marine Ecology supported by the Norwegian Research Program for Marine Arctic Ecology (Pro Mare).

\section{References}

Barlow, R., Gosselin, M., Legendre, L., Therriault, J-C., Demers, S., Mantoura, R. F. C. \& Llewellyn, C. A. 1988: Photoadaptive strategies in sea-ice microalgae. Mar. Ecol. Prog. Ser. 45, 145-152.

Bedo, A. W., Head, E. J. H., Conover, R. J., Horne, E. P. W. \& Harris, L. R. 1990: Physiological adaptations of an under-ice population of Pseudocalanus in Barrow Strait (N.W.T.) to increasing food supply in spring. Polar Biol. 10, 561-570.

Bradstreet, M. S. W. \& Cross, W. E. 1982: Trophic relationships at high arctic ice edges. Arctic 35, 1-12.

Bradstreet. M. S. W., Finley, K. J., Sekerak, A. D., Griffiths, W. B., Evans, C. R., Fabijan, M. F. \& Stallard. H. E. 1986: Aspects of the biology of Arctic cod (Boreogadus saida) and its importance in arctic marine food chains. Can. Tech. Rep. Fish. Aquat. Sci. 1491

Carcy, A. G., Jr. 1985: Marine Ice Fauna: Arctic. Pp. 173-190 in Horner. R. A. (ed.): Sea lce Biota. CRC Press, Boca Raton, Florida.

Conover, R. J., Herman, A. W., Prinsberg, S. J. \& Harris, L. R. 1986a: Distribution of and feeding by the copepod Pseudocalanus under fast ice during the arctic spring. Science 232, 1245-1247.

Conover, R. J., Durvasula, R., Roy, S. \& Wang, R., 1986b: Probable loss of chlorophyll-derived pigments during passage through the gut of zooplankton, and some of the consequences. Limnol' Oceanogr. 31, 878-887.

Conover, R. J., Bedo. A. W., Herman, A. W., Head, E. J. H., Harris, L. R. \& Horne. E. P. W. 1988: Never trust a copepod - some observations on their behaviour in the Canadian Arctic. Bull. Mar. Sci. 43, 650-662.

Corkett, C. J. \& McLaren, I. A. 1978: The biology of Pseudocalanus. Adv. Mar. Biol, 15, 1-231.

Daly, K. 1990: Overwintering development, growth, and feeding of larval Euphausia superba in the Antarctic marginal ice zone. Limnol. Oceanogr. 35, 1564-1576.

Edmondson. W. T. 1965: Reproductive rate of planktonic rotifers as related to food and temperature in nature. Ecol. Monographs 35, 61-111.

Frost, B. W. 1989: A taxonomy of the marine calanoid copepod genus Pseudocalanus. Can. J. Zool. 67, 525-551.

Gosselin, M., Legendre, L.. Demers, S. \& Ingram, R. G. 1985: Responses of sea-ice microalgae to climatic and fortnightly tidal energy inputs (Manitounuk Sound, Hudson Bay). Can. J. Fish. Aqual. Sci. 42, 999-1006 
Lepage. S. \& Ingram, R. G. 1991: Variation of upper layer dynamics during breakup of the seasonal ice cover in Hudson Bay. J. Geophys. Res. 96, 12711-12724.

Lund, J. W. G., Kipling. C. \& Lecren. E. D. 1958: The inverted microscope method of estimating algal numbers and the statistical basis of estimation by counting. Hydrobiologia 11 , 143178.

McLaren. I. A., Sevigny, J. M. \& Corkett. C. J. 1989: Temperature-dependent development in Pseudocalanus species. Can. J. Zool. 67, 559-564.

Michel, C. Legendre, L., Demers, S. \& Therriault, J.-C. 1988: Photoadaptation of sea-ice microalgae in springtime: photosynthesis and carboxylating enzymes. Mar. Ecol. Prog. Ser. $50,177-185$.

Ohman, M. 1985: Resource-satiated population growth of the copepod Pseudocalanus sp. Arch. Hydrobiol. Beih. Ergebn. Limnol. 21, 15-32.

Runge. J. A. 1984: Egg production of the marinc. planktonic copepod. Calanus pacificus Brodsky: Laboratory observations. J. Exp. Mar. Biol. Ecol. 74, 53-66.

Runge. J. A. \& Ingram. R. G. 1988: Underice grazing by planktonic, calanoid copepods in relation to a bloom of ice microalgae in southeastern Hudson Bay. Limnol. Oceanogr. 33. $281-286$.

Runge. J. A. \& Ingram. R. G. 1991: Under-ice feeding and dicl migration by the planktonic copepods Calanus glacialis and Pseudocalanus minutus in relation to the ice algal pro- duction cycle in southeastern Hudson Bay. Mar. Biol. 108. 217-226.

Sekerak. A. D. 1982: Young-of-the-year cod (Boreogadus) in Lancaster Sound and Western Baffin Bay. Arctic 35, 75-87.

Simard. Y. . Lacroix. G. \& Legendre, L. 1985: In situ twilight grazing rhythm during diel vertical migrations of a scattering layer of Calanus finmarchicus. Limnol. Oceanogr. 30, 598606.

Smith, S. L. 1990: Egg production and feeding by copepods prior to the spring bloom of phytoplankton in Fram Strait. Greenland Sea. Mar. Biol. I06, 59-69.

Stretch. J. J., Hamner, P. P., Hamner, W. M., Michel, W. C., Cook. J. \& Sullivan. C. 1988: Foraging behaviour of antarctic krill Euphausia superba on sea ice microalgae. Mar. Ecol. Prog. Ser. 44, 131-139.

Tande. K. S. \& Hopkins. C. C. E. 1981: Ecological investigations of the zooplankton community of Balsfjorden, Northern Norway: The genital system in Calanus finmarchicus and the role of gonad development in overwintering strategy. Mar. Biol. 63, 159-164.

Tourangeau. S. \& Runge, J. A. 1991: Reproduction of Calanus glacialis in relation to an ice microalgal bloom in southcastern Hudson Bay. Mar. Biol. 106, 227-234.

Tremblay. C. T., Runge, J. A. \& Legendre, L. 1989: Grazing and sedimentation of ice algae during and inmediately after a bloom at the ice-water interface. Mar. Ecol. Prog. Ser. 56, 291-300. 